\title{
LISTENING COMPREHENSION DIFFICULTIES; A CASE STUDY OF EFL STUDENTS IN LISTENING CLASS
}

\author{
Asep Hardiyanto \\ Universitas Mubammadiyah Kotabumi \\ asep.hardiyanto@umko.ac.id \\ Mutia Tanjung \\ Universitas Muhammadiyah Kotabumi \\ Mutiatanjung97@gmail.com \\ Sigit Suharjono \\ Universitas Muhammadiyah Kotabumi \\ Sigit.suharjono67@gmail.com
}

\begin{abstract}
Listening skill in English is one of the most important skills in communication and educational process. However, listening skill is a skill that is not easily mastered by all non-native speaker students. The students need to know and understand the difficulties in listening process. Therefore, the current study aims to investigate the difficulties faced by the students dealing with listening comprehension. This research is a descriptive qualitative research with case study approach that examines six students in third semester of the English education study program in Universitas Muhammadiyah Kotabumi with three different proficiency levels: low, moderate, and high level. The results of this study showed that students with low level faced difficulties with unfamiliar words (message content), speed of speech (speaker), and lack of vocabulary (listener). Then in moderate level students felt difficult in the speed of speech (speaker) and noises (physical settings). Meanwhile, students with high level faced difficulty with the long spoken text (message content), variety of accents (speaker) and noises (physical settings). It can be concluded that the listening comprehension difficulties encountered by the students at tertiary level are different depending on their proficiency in English. Therefore, the implication of the current study is that the lecturer need to consider the information revealed in this study in order to be able to overcome the difficulties faced by the students.
\end{abstract}

Keywords: Listening Skill, Listening Comprehension, Listening Difficulties

\section{A. INTRODUCTION}

$\mathrm{I}$

$\mathrm{n}$ english as a foreign language setting, it was acknowledged that listening is a psycological process which is very complex in which it involves perception, cognition, attention and memory. Doing listening activity is believed to be able to help learners in improving their speaking skill. It is supported by Mandelsohn in Bingol et al (2014) which stated that from the time allotment which is spent on communication, listening takes up 40 $50 \%$; speaking $25-30 \%$, reading $11-16 \%$, and writing about $9 \%$. It makes listening has an important role in communication.In addition, Gebhard (2000) stated that listening is an active skill where listeners need to be received to the others, which includeserious attention to explanations, opinions and questions. In receiving something, listeners will hear language 
produced by people first, process the words until they can respond with what they mean. As Rost cited in Hien (2015) said that listening as foreign language is the principal thing since it provides the language input. Further, as an input skill, listening plays an important roles inthe development of students' language.

In terms of test of English as a foreign language, listening become the first skill to be tested. It means that this skill is very important to be mastered by the students. Consequently, the setting of learning listening should be more enjoyable so that they get used to it and add a lot of insights. People listened to a various and different sources everyday. What and how were they listening are depending on their purposes. A good listening skill seems to be difficult to acquire for the students who learn English as a foreign language setting.

Furthermore, in somecases of language classroom, listening isseen as the most difficult language skill since it needs a lot of concentrations and deep attentions to comprehend the listening passage or materials that include understanding the dialogue and monologue text. Moreover, listening can be stressful and even trigger the anxiety. Susilowati (2019, p.14) argues "if students do not aware of some listening difficulties they face during listening, it is possible that it can diminish their interest to learn and increase their anxiety". Additionally, Bingol et al (2014) reveals that the speakers' accent and unfamiliar vocabulary are the causes of listening difficulties.

Regarding to listening difficulties, several researchers have been carried out the similar studies such as Hamouda (2013) who investigated the problems related to listening comprehension employed by the students in Saudi. From sixty participants of the first-year students-aged 20 to 22 years old-majoring in English and Translation of Qassim University, hefound that the students' problems in listening were dealing with pronunciation, speed of speech, insufficient vocabulary, different accent of speaker, lack of concentration, anxiety, and bad quality of recording.

Another piece of related research conducted by Yilmaz and Yavuz (2015). This research examined the frequency of problems in listening comprehension faced by the students in Turkey seen from three listening category such as problem based on teachers, students own strategy and learners' psycology. The result revealed that the most problems faced by the students is about learning and teaching phonetics which belongs to their own strategy. Moreover, Yahmun, Sumarti and Setyowati (2020) carried out an investigation about the students' listening difficulties privat universities in Malang. Their finding showed that thelistening difficulties faced by the students are the speed and the lenght of the record. 
Having analyzed those related previous studies, however, an investigation of listening difficulties based on the students' english proficiency level has not been conducted yet. Thus, the current study focus on listening difficulties encountered by the students of English education study program of Universitas Muhammadiyah Kotabumi. Therefore, the research question formulated is "what are the listening difficulties encountered by the students of English education study program of Universitas Muhammadiyah Kotabumi?”. By investigating this case, it is expected that the result of this study will give beneficial impact to the treasure of related knowledge both theoretically and practically.

\section{B. LITERATURE REVIEW}

\section{Listening Difficulties}

Generally, the students' difficulties dealing with listening is that they did not have such a good vocabulary bank in their memory. It was supported by Goh in Yilmaz and Yavuz (2015) the most common difficulties employed by students in listening are quickly forgetting what is listened, understanding the message but not the intended message, not recognizing the words they know, ignoring the following part while thinking about the meaning, and enabling to form a psycological representation from words heard. Besides, Yagang (1994) indicates the sources of listening difficulties mainly came from four aspects: the message content, the speaker, the listener, and the physical settings.

\section{The content message}

The listening lesson could deal with almost any area of life. It perhaps including daily activities, hobbies and also other situations in students' life. Even in a spontaneous or direct conversation, speakers switch topics frequently and the content is not well organized (Hamouda, 2013). For several cases listeners cannot predict what speakers said and also cannot be heard to the slowly speed, whether it is a daily conversation, news report on the audio media such as radio, etc. Even in dialogues it seems impossible to command the speaker to repeat something as much time as the listener might like. Particularly, grammatical structures complexity, longer spoken text, unfamiliar words or topic, a topic that cannot generate listeners' interest pose listening difficulties to the listeners (Hamouda, 2013).

\section{The speaker}

The speaker is a part of material which facilitates students to hear. Trismasari et al (2016) stated that students sometimes get difficulties in listening which related to the speaker because sometimes the speaker speak too fast. Especially when the speaker speaks with unclear 
pronunciation so listener cannot catch the words, they get distracted and unable to continue to process the information. Additionally, they found it difficult to understand speakers with different accents. Juan and Abidin (2013) stated that different speakers use different accents, which sometimes the students are not easily understood.

\section{The listener}

Yang and Chen in their research (2007) pointed that the main source of difficulty in listening came from listener him/herself. Their comprehension controlled by their proficiency level. Connected with Hanoi in Hamouda (2013) who stated that students' limited vocabulary be the major problem that interfering listening comprehension to understand the message. Students felt stressed and lost interest when they cannot understand the message being spoken to them. The failure to recognize words also could inhibit students' ability to separate words in connected speech (Underwood in Hamouda, 2013). Besides, they are lack of factual, contextual knowledge of the target language and socio-cultural could present the hindrances of comprehension (Anderson and Lynch in Yagang, 1994).

Moreover, Flowerdew and Miller (1992) stated that a big problem that students face in listening comprehension was inability to concentrate. The failure of concentration will make students missing some of the contents which will influence their understanding of the material eventually. During listening process students need to be attentive due to the very restricted time to process and understand the component of newly introduced information (Hamouda, 2013).

\section{Physical settings}

Noises, as stated by (Yagang, 1994)including both environmental noises and basenoises on the recording can make the listener's mind off the substance of the listening passage. Even thoughthey try hard to focus they would still get distracted by noises. Additionally, the difficulty could come from the listening equipments such as video recording, tape or other devices. The bad or poor recording quality tapes or disks can also annoy the listener's comprehension.

\section{Major Problems In Listening Comprehension}

As stated before, listening is the crucial as well as difficult subject to be mastered by the students so that sometimes it becomes problems to them. According toUnderwoodin Gilakjani and Ahmadi (2011) there are seven major problems in listening comprehension; (1)Listeners cannot control the delivery speed. Listener may feel difficult to catch the targetwords if the speakers speak faster than normal (Bingol et al, 2014); (2) Listeners cannot 
always get words being repeated. In the classroom, listener could not decide to reply the recording or a section they want to be repeated. Especially when they have to translate the message lively. Translation often encounters problems of non-equivalences in various levels that looks like impossible to get the whole message correctly (Suharjono, 2018); (3)Listener's limited of vocabulary. Maulidiyah (2017) said that the major problem interfering listening comprehension was the students' vocabulary were too limited to understand the message.It is important to enrich vocabulary because the more students get the vocabulary, the easier students improve their English (Setiani,2018; Hardiyanto, 2020); (4) Failure to identify the signals. Listeners could fail to recognize the signals which denote the speaker that the speaker is shifting from one point to other point, replicating a point, or providing an example (Gilakjani and Ahmadi, 2011); (5) Listener may lack of contextual knowledge. Listener may have substantial difficulties in comprehending the entire meaning unless the context is wellknown for the listener (Gilakjani and Ahmadi, 2011). Further, they said that nonverbal clues such as the expressions of the face, body language, or tone of voice can also be easily misinterpreted by listeners from the disparate cultures; (6) Inability to concentrate. As concentrate one of the parts in psychological process, it is relatively complex in listening comprehension process. It is hard for students to highly concentrate on interpreting a strangesounds, words, and sentence for such long periods (Yagang, 1994);(7) Established learning habits. Listener are wondering if they fail to comprehend particular phrase or word and they will be dishearten by the failure. It is normal to tolerate obscurity and incompleteness of comprehending also increase their self-esteem that can give listener positive vibe to success in learning. Susanti (2018) argued that self-esteem considered as the important factor that can help students build positive mind about themselves which can maximize their potential talent to be successful. So that beside they can established their learning they also improve their selfesteem.

\section{METHOD}

The currentstudyused qualitative research with case study approach that examined six students with three different English proficiency levels; low ability, moderate ability, and high ability level students. 


\section{Participants}

The researcher analyzed six students-low, moderate and high english proficiency levelrelated to their listening difficulties covering four aspects of listening difficulties: the message content, the listener, the speaker, and physical settings.

\section{Instruments}

To collect the data, instruments used in this research was open-ended interview guideline and lecturer's documents. In the specification of interview guideline, researcher asked the student about their perception towards learning listening then asked their difficulties during learning listening within their strategies in overcoming the difficulties. Moreover, lecturer's documents used to choose the respondents depend on their final result by arranging students' score and then chose their level of ability.

\section{Data Collecting Technique}

In collecting the data, the following procedures were implemented

a. Interview

In order to get deeply and naturally data, researcher used open-ended interview which the researcher asked several questions to students that has been provided and arranged before.

b. Documentation

In this research, researcher collected the lecturer's documents in the form of students' final result as the evidence in the research also to choose the students as the respondent of this research.

\section{Data Analysis}

To obtain an accurate findings, the researchers analyzed the data through three activities: data condensation, data display, drawing and verifying conclusionsintroduced by Miles, Huberman\& Saldana (2014). First, interview toward six students who have been selected before. Second, in the data condensation, the data gotten were transformed into interview transcription. Third, in data display, the datawere organized and displayed in form of table. Lastly, after reduction and display, the researchers drawn and verified the conclusions based on research questions formulated previously. 


\section{RESULT AND DISCUSSION}

The main theory used to classify the students' difficulties faced by the students in listening classroom is that from Yagang (1994) who said that there are four categories of students difficulties; message content, speaker, listener and physical setting. Thus, those four aspects become the things being analyzed by the researchers.

Based on the research result, it was found several informationsrelated to the students' difficulties in listening such as (1) message content; unfamiliar words, words of incoming speech and long spoken text (2) speaker; visual needed, speed of speech, and variety of accents (3) listener; less focus, lack in vocabulary, inability to understand meaning and inability to recognize familiar words and (4) physical settings; noises. In detail, the students' difficulties were served in the following table.

Table. 1. Students' Listening Difficulties

\begin{tabular}{|c|c|c|c|c|c|c|c|c|}
\hline \multirow{3}{*}{ No } & \multirow{3}{*}{$\begin{array}{l}\text { Types of } \\
\text { Difficulty }\end{array}$} & \multirow{3}{*}{ Kind of Difficulty } & \multicolumn{6}{|c|}{ Participants/Respondents } \\
\hline & & & \multicolumn{2}{|c|}{ Low } & \multicolumn{2}{|c|}{ Moderate } & \multicolumn{2}{|c|}{ High } \\
\hline & & & SA & MFW & $\mathrm{AM}$ & HPA & APS & AJS \\
\hline \multirow{3}{*}{1} & \multirow{3}{*}{$\begin{array}{l}\text { Message } \\
\text { Content }\end{array}$} & Unfamiliar word & $\sqrt{ }$ & $\sqrt{ }$ & - & - & - & - \\
\hline & & Word of incoming speech & - & - & - & - & $\sqrt{ }$ & - \\
\hline & & Long spoken text & - & - & $\sqrt{ }$ & - & $\sqrt{ }$ & $\sqrt{ }$ \\
\hline \multirow{3}{*}{2} & \multirow{3}{*}{ Speaker } & Visual needed & - & $\sqrt{ }$ & $\sqrt{ }$ & $\sqrt{ }$ & - & $\sqrt{ }$ \\
\hline & & Speed of speech & $\sqrt{ }$ & $\sqrt{ }$ & $\sqrt{ }$ & $\sqrt{ }$ & - & - \\
\hline & & Variety of accents & $\sqrt{ }$ & - & - & $\sqrt{ }$ & $\sqrt{ }$ & $\sqrt{ }$ \\
\hline \multirow{4}{*}{3} & \multirow{4}{*}{ Listener } & Less Focus & $\sqrt{ }$ & - & - & $\sqrt{ }$ & - & $\sqrt{ }$ \\
\hline & & Lack in vocabulary & $\sqrt{ }$ & $\sqrt{ }$ & $\sqrt{ }$ & - & - & - \\
\hline & & $\begin{array}{l}\text { Inability to understand } \\
\text { meaning }\end{array}$ & - & $\sqrt{ }$ & - & - & $\sqrt{ }$ & - \\
\hline & & $\begin{array}{l}\text { Inability to recognize } \\
\text { familiar word }\end{array}$ & - & - & - & - & - & $\sqrt{ }$ \\
\hline \multirow{2}{*}{4} & \multirow{2}{*}{$\begin{array}{l}\text { Physical } \\
\text { Settings }\end{array}$} & Noises & - & $\sqrt{ }$ & $\sqrt{ }$ & $\sqrt{ }$ & $\sqrt{ }$ & $\sqrt{ }$ \\
\hline & & Poor Equipment & - & - & - & - & - & - \\
\hline \multicolumn{3}{|r|}{ TOTAL } & 5 & 6 & 5 & 5 & 5 & 6 \\
\hline
\end{tabular}

As we can see from the types of the difficulties mentioned by Yagang (1994), difficulties in listening divided into four aspects; Message Content, Speaker, Listener, and Physical Settings. In each types of difficulties, there are kind of difficulty found along the interview with six respondents. Start with the difficulty in the message content, the researcher got three kinds of difficulties, first, researcher found two students had difficulty with the unfamiliar word. When students listen to the audio given, they found some of unfamiliar words that made them uneasy to understand the context of the audio given. Else, it comes to the word of incoming speech, students already felt worry to the incoming words, this could make student 
did not want to continue the listening process. Moreover, in a long spoken text, it found three students felt difficult when they have to listen to a long passage especially when the spoken text combined with the unfamiliar words. As Bingol (2014) defined that student play a great role when they listen to long parts of spoken text and keeping all the information in their mind. This kind of difficulty made them afraid to listen to the audio given and understand the whole content.

Second, the difficulty related to the speaker or person who speaks in the audio given. This type of difficulty discovered three kinds of difficulties. It begins with the visual needed. Students tend to be difficult to get speakers said if they did not see what speakers are doing. This is reinforced with statement by Hamouda (2013) that the majority of learners find it difficult to understand the meaning of the spoken text without seeing the speakers' body language. Students agreed that visual need by the listener especially as an EFL. Next, kind of difficulty in the speed of speech. It found four students felt this difficulty, as an EFL they said the speed of the speaker's speech sometimes made them confused and hard to understand. They often miss some words or sentence which made them cannot get what the listening contents are. Other kind of difficulty is the speakers' accents. Four students felt confuse with what speaker's are talking about if they listen to the accent which different from what they usually heard. When listener heard unfamiliar accents such as Indian English for first time after studying only American English, it will encounter critical difficulties in listening (Buck, 2001). These difficulties mostly found by researcher during the interview and observation.

Third, it comes to the difficulty in listener or the students itself. In this type, there are four kinds of difficulties, it starts with less focus. Students stated that they sometimes lose their concentration. Student felt less focus when they have to listen to the audio and at the same time they should search for the answer. They also got bored easily. Then the other difficulty was the lack in vocabulary. This is the most difficult kind of difficulty in listening for students. They admitted that they still lack in vocabulary which cause them to stop and think about the meaning of several words and miss the next part of speech or some essential information. Other difficulty was student claimed their inability to recognize familiar word and understand the meaning of some words. In line with Underwood in Jiang (2009) that an unknown word could be a suddenly dropped barrier causing listeners stop, think about meaning, and miss out the next part of the speech. This made students lost what speakers said. Even when they familiar with the word, they still cannot recognize the word or the meaning also. 
Last, the types of difficulty in physical settings. From the result of the research, this type of difficulty was the less difficulty for students. The researcher found noises was the only kind of difficulty acknowledged by students. Students claimed the noises came from their class, especially the noises of classmates when they were learning listening. It is supported by Hamouda (2013) that noises could take listeners' mind off from the content of the listening passage. Noises could disturb their concentration in listening and did not get the content of the audio given. Students stated that they still could handle this difficulty by reminded to keep silent while learning listening to each other.

Besides, researchers also divided the respondents into three categories of their ability level; low, moderate and high to see the differences of difficulties in each level. All the respondents from low, moderate and high ability level faced difficulties in listening comprehension. All difficulties related to the message content, the speakers, the listener, and physical setting. For low ability students, they felt difficult with unfamiliar word which related to the message content, difficult with the speed of speech and accents from the speaker, less focus or lack of vocabulary and sometimes unable to understand meaning when it comes from the listener itself, and they felt the noises as the difficulty which related to the physical setting.

For moderate ability students, when it comes to the message content they felt difficult with the long spoken words, speed and accent which related to speaker, for the listener itself less focus and lack of vocabulary became their difficulties, and for the physical setting they felt difficult with the noises. Last, for the high ability students, they felt difficult with long spoken and incoming speech which related to the message content, they felt difficult with the speaker accent, less in focus and sometimes cannot recognize the words came from the listener itself and for the physical setting factor they felt difficult with the noises.

Having seen those results above, it seems all the difficulties found were similar with the previous findings found by others scholars; (Hamouda:2013, Yilmaz and Yavuz:2015, and Yahmun, Sumarti and Setyowati:2020). However, the aspect of poor equipment was not found in this study. The most aspect of difficulties found was lack of vocabulary. Vocabulary become one of the factors which influence students' listening comprehension. It was strengthened by Darti and Asmawati (2017) who said that vocabulary is one of the hindrances faced by the students in learning listening ability. It can be concluded that the current finding has similarities and differences with the previous studies in several context. 


\section{E. CONCLUSION}

Referring to the research findings and discussion, it can be concluded that the difficulties are found to vary from six students in low, moderate and high ability level. In the low ability students found that unfamiliar words are the most difficulty in message content aspect, then difficult with speed of speech in the speaker aspect and feel lack in vocabulary which came from the listener aspect or themselves. The moderate ability level students found that the difficulty which related to the speaker is the speed of speech and the noises in physical setting aspect. While in high ability students level, long spoken text became the most difficulty which related to the message content, difficult with variety accents in speaker aspect and the noises in physical setting aspect. Having known this result, it is then suggested that students need to practice their listening skill regularly and enrich their vocabulary mastery. Researcher also hopes this research could be used as a reference for future research.

\section{REFERENCES}

Bingol, B. Celik, N. Yildiz and C. Tugrul Mart. (2014). Listening Comprehension Difficulties Encountered by Students in Second Language Learning Class. Vol.2 (1): 1-6 Available:http://www.wjeis.org/FileUpload/ds217232/File/01b.bingol.pdf (May, $3^{\text {rd }}$ 2020)

Darti, and Asmawati, A. (2017). Analyzing Students' Difficulties Toward Listening Comprehension. ETERNAL. Vol. (3) No. 2. 56-76

Flowerdew, J., and L. Miller. (1992). Student Perceptions, Problems and Strategies in Second Language Lecture Comprehension. In RELC journal. Vol. 23(2): 60-80.

Gebhard, J.G. (2002). Teaching English as a Foreign Language. USA: The University of Michigan Press.

Gilakjani, A.P and M.R. Ahmadi. (2011). A study of Factors Affecting EFL Learners' English Listening Comprehension and the Strategies for Improvement. Journal of Language Teaching and Research. Vol. 2 (5): 977-988. Available:

Gilakjani, A.P and N.B. Sabouri. (2016). Learners' Listening Comprehension Difficulties in English Language Learning: A Literature Review. In Canadian Center of Science and Education Publisher. Vol. 9 (6): 123-133. Available: http://dx.doi.org/10.5539/elt.v9n6p123 (May, 3 ${ }^{\text {rd }} 2020$ )

Hamouda. A. (2013). An Investigation of Listening Comprehension Problems Encountered by Saudi Students in the EL Listening Classroom. International Journal of Academic Research in Progressive Education and Development. Vol. 2 (2): 114-155

Available: http://hrmars.com/admin/pics/1882.pdf (May, $2^{\text {nd }} 2020$ ) 
Hardiyanto, A. (2020). Developing E-Book for Pre-Intermediate Grammar in EFL Classroom. PREMISE: Journal of English Education and Applied Linguistic. Vol. 9 (2). 129142. Retrivied from http://ojs.fkip.ummetro.ac.id/index.php/english/article/view/3058/pdf.

Hien, T. V. (2015). Difficulties and Stategies in Listening Comprehension.Truong Dai Hoc Lac hong: Lac Hong university. Available:https://lhu.edu.vn/139/662/DIFFICULTIES-AND-\%20STRATEGIES$\% 20 I N \% 20$-LISTENING\%20COMPREHENSION-TRINH-VINH-HIEN03AV4.html

Jiang, Yongmei. (2009). Predicting Strategy and Listening Comprehension. In Asian Social Science, Vol. 93-97.

Available:http://www.ccsenet.org/journal/index.php/ass/article/view/540

Juan, W.X., and M.J.Z. Abidin. (2013). English Listening Comprehension Problems of Students from China Learning English in Malaysia. In Language in India, Vol. 13 (4): $367-$ 404.Available:http://www.languageinindia.com/april2013/chinastudentsenglishfinal.pd f (March, 22nd 2020)

Maulidiyah, N. (2017). The Students' Problems in Listening Comprehension. In LET: Linguistics, Literature and English Teaching Journal. Vol. 5(1): 1-18. Available:https://jurnal.uin-antasari.ac.id/index.php/let/article/view/1419/0 (March, $\left.23^{\text {rd }} 2020\right)$

Miles, M.B., Huberman, A.M., \& Saldana, J. (2014). Qualitative Data Analysis; A Method Sourcebook $3^{\text {rd }}$ Edition. USA. Sage Publications Inc.

Setiani, R. (2018). The Implementation of Lesson Study to Improve Students' Vocabulary Mastery Through Team Accelerated Instruction (TAI). In JurnalEdukasi Lingua Sastra, Vol. 16 (1): 33-38. Available: https://jurnal.umko.ac.id/index.php/elsa/article/view/76 (September, $\left.4^{\text {th }} 2020\right)$

Suharjono, S. (2018). Analysis of Translation Shift in the Indonesian Translation DalihPembunuhanMassal: Gerakan 30 September danKudeta Suharto by John Roosa of an English Document Pretext For Mass Murder: The September 30th Movement and Suharto's Coup D'état in Indonesia. In JurnalEdukasi Lingua Sastra, Vol. 16 (1): 11-21.

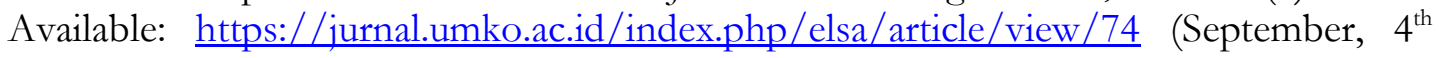
2020)

Susanti, E. (2018). Students' Self-Esteem of the First Year English Education Study Program in STKIP MuhammadiyahKotabumi. In JurnalEdukasi Lingua Sastra, Vol. 15 (2): 20-30. Available: https://jurnal.umko.ac.id/index.php/elsa/article/view/64 ${\text { (September, } 6^{\text {th }}}^{\text {the }}$ 2020)

Susilowati, R. (2019). Listening Anxiety and The Solutions to Inhibit Its Negative Effects. In JurnalEdukasi Lingua Sastra, Vol. 17(2): 13-26.

Available:https://jurnal.umko.ac.id/index.php/elsa/article/view/36 (September, $4^{\text {th }}$ 2020) 
Trismasari, M., Sudarsono, and Eni, R. (2016). Factors Influencing English Listening Difficulties. In JurnalPendidikandanPembelajaranKhatulistiwa. Vol. 5 (12): 1-13. Available: https://jurnal.untan.ac.id/index.php/jpdpb/article/view/17738 (August, 1st 2020)

Yagang, F. (1994). Listening: Problems and solutions. In T. Kral (ed.) Teacher Development: Making the Right Moves. Washington, DC: English Language Programs Divisions, USIA.

Yahmun, Sumarti, E., Setyowati,D., (2020). Listening Difficulties faced by the first semester students at Basic Listening Class. Journey. Vol. 3(1):57-61

Yang, M. N., and Chen, S. C. (2007). An investigation on junior college students' learning problems in English-learning programs on the radio. Language. Text. Society. Vol. 1 (2): 106-118. Available: https://cyberleninka.ru/article/n/an-investigation-on-juniorcollege-students-learning-problems-in-english-learning-programs-on-the-radio/viewer (March, 23 ${ }^{\text {rd } 2020)}$

Yilmaz, H., and F. Yavuz. (2015). The Problems Young Learners Encounter During Listening Skills. In ELSEVIER publisher. Vol. 197 : 2046-2050. Available:https://www.sciencedirect.com/science/article/pii/S1877042815045899 (May, 16 ${ }^{\text {th }} 2020$ ) 